\title{
From Conflicts to Integration: An Empirical Study on Chinese EFL Learners' Construction of Bilingual Identities
}

\author{
Fen Xue \\ Foreign Language Department, Tourism \& Culture College of Yunnan University, Yunnan, China \\ Baijing Han \\ Foreign Language Department, Lijiang Teachers' College, Lijiang, Yunnan, China
}

\begin{abstract}
By adopting both quantitative and qualitative methods, this paper, with the types of bilingual identities (Yongwei B \& Yihong G,2006) serving as the framework, examines the characteristics of Chinese college English learners' bilingual identity changes. It is found that instrumental bilingual identity penetrates through L2 learning process, additive and productive bilingual identity are dominant types among L2 English learners; the bilingual identity construction of EFL learners may assume the following process: instrumental bilingual identity, subtractive and split bilingual identity, additive and productive bilingual identity. The study indicates the conflicts and integration of bilingual identities experienced by L2 English learners in China.
\end{abstract}

Index Terms - English learning, bilingual identities, identity construction, conflict, integration

\section{INTRODUCTION}

Language is not only a tool for communication, but also an embodiment of a culture. Therefore, the acquisition of a second language which includes its cultural knowledge will make the learners' cultural identity undergo significant changes. To be specific, learners may reevaluate and reorientate their cultural values, group identity, and communication styles, hence the study on language learners' cultural identity changes is of high practical value. Then questions arise as: what are the characteristics of EFL learners' changes in bilingual identity which includes language identity and cultural identity? What's the relationship between language learning and identity construction? Language learners' bilingual identity changes penetrate the whole process of language learning,so probes into these questions will facilitate our understanding of the development of learners' cognitive ability and cultural identity, which may provide implication for more rational and comprehensive practices on foreign language teaching.

\section{LITERATURE REVIEW}

Theoretically, Lambert (1972; quoted in Yihong G,2004)proposed two types of bilingualism, i.e., subtractive and additive bilingual identity. Subtractive bilingual identity refers to that learners' native language and culture identities are gradually replaced by the second language and culture, while additive bilingual identity means learners acquire a new language and culture while remaining their native language and culture identities. Most researchers regarded additive bilingualism as ideal although Schumann and others (1978; quoted in Yihong G, 2004) advocated the subtractive bilingualism which is characterized as complete acculturation. In 2001, Chinese scholar Yihong Gao put forward a term as productive bilingualism, which means both native and target language/culture are promoted in second language learners when they interact with each other, thus improving learners' ability in overall cognition, affect and communication. The difference between productive and additive bilingualism lies in that the former emphasizes the mutual enhancement between native language/culture and target ones, while the latter indicates the two languages/cultures have their respective functions in different settings without interaction. Therefore, productive bilingualism is generally viewed as a more ideal type for bilingualism.

Empirically, many studies on Chinese EFL learners' cultural identity changes have been made from various perspectives. Zhanzi L (2007) examined English learners' autobiographical accounts of cross-cultural experiences by adopting a discourse analysis approach. The results revealed identity conflicts and changes experienced by learners. The research conducted by Yuxin R (2008) suggested learners always play double (or multiple) roles in cross-cultural communication, while different roles are salient in different situations. Based on a large scale of quantitative investigation, Yihong G et al (2003) together with some other scholars found the productive bilingualism is "not limited to the best EFL learners" but presented in common learners; in addition, productive and additive bilingualism are dominant among college students, while subtractive and split bilingualism also exist; furthermore, the productive bilingualism may positively correlated with learners' language proficiency. By examining qualitative data in the learners' written self-reports, Yongwei B \& Yihong G,(2006)explored the learners' attitudes (affect, appreciation and 
judgment) towards English study and culture learning. It was found that learners may follow the process from subtractive bilingualism to productive bilingualism, which demonstrates learners' tolerance of cultural differences and the integration of their bilingual identities.

All the above theoretical analysis and empirical studies have provided implication for the present research on EFL learners' dynamic construction of bilingual identities in China. Most of them, however, fall into either quantitative or qualitative paradigm. With bilingual types (Yongwei B \& Yihong G, 2006) serving as the theoretical framework, the present study, by adopting both quantitative and qualitative methods, will explore the EFL learners' developmental patterns of bilingual identities which include their language and culture attitude. The implication for foreign language teaching will also be probed.

\section{RESEARCH QUESTIONS}

The present study will explore Chinese EFL learners' developmental patterns of bilingual identities across different levels of proficiency. To be specific, there are two questions as follows:

1. What is the general characteristics of Chinese EFL learners' bilingual identities with bilingual types (Yongwei B \& Yihong G, 2006) serving as the analytical framework?

2. What kind of developmental pattern do EFL learners display in terms of different levels of proficiency?

\section{Methodology}

\section{A. Participants}

A total number of 105 students from different grades in Tourism and Culture College took part in this study. With English proficiency test in China (i.e., CET4 and TEM4)functioning as the measurement, the students were classified into three groups, i.e., 32 low-proficiency learners who haven't passed CET4, 31 intermediate learners who have passed CET4, and 42 high-proficiency learners who have passed TEM4. Their age ranged between 18 and 22. Low-proficiency learners and intermediate learners were all graduate students of different majors, while high-proficiency learners were from English majors. The sample consisted of both male and female students.

\section{B. Instrumentation}

Two kinds of research paradigms were used the present study, in which a questionnaire was used to collect quantitative data, while learners' autobiographical accounts provided qualitative material.

1. Questionnaire

The questionnaire consists of thirty-nine questions that are divided into two sections: a demographic section and questionnaire to investigate learners' cultural identity changes (see appendix). The questionnaire was developed based on Yongwei B \& Yihong G's theoretical framework of bilingual types and Yihong G's survey of cultural identities, so as to ensure its reliability and validity. Five types of bilingual identities, in which seven situational statements were designed for each type, were included in the survey to test participants' attitude towards English study and culture learning (see table 1). So there are totally thirty-five items of five-point Likert-type scale ranging from strongly disagree to strongly agree for assessing the degree of learners' agreement with the given option. The higher score a participant assesses in a certain sentence, the more he/she agrees on the statement.

TABLE 1.

FIVE BILINGUAL TYPES AS VARIABLES

\begin{tabular}{|l|l|l|l|}
\hline Variables & Meaning of variables & Operational statements of variables & $\begin{array}{l}\text { Items in the } \\
\text { questionnaire }\end{array}$ \\
\hline $\begin{array}{l}\text { Instrumental } \\
\text { bilingual identity }\end{array}$ & $\begin{array}{l}\text { Learners regard English langu- age as a } \\
\text { tool to achieve certain goals in their life. }\end{array}$ & English for me is a stepping-stone to get a job. \\
\hline $\begin{array}{l}\text { Subtractive } \\
\text { bilingual identity }\end{array}$ & $\begin{array}{l}\text { Learners' native language and cultural } \\
\text { concepts are gradually replaced by the } \\
\text { foreign ones. }\end{array}$ & $\begin{array}{l}\text { Ifound my communication styles and behaviors were } \\
\text { a little westernized after learning English for many } \\
\text { years. }\end{array}$ & $\begin{array}{l}1,8,10,13, \\
16,18,28\end{array}$ \\
\hline $\begin{array}{l}\text { Split } \\
\text { bilingual identity }\end{array}$ & $\begin{array}{l}\text { Learners experience contradic- tion and } \\
\text { conflicts between their native } \\
\text { language/culture and the target ones. }\end{array}$ & $\begin{array}{l}\text { Ifound traditional Chinese concepts often conflict } \\
\text { with English concepts, which makes me confused } \\
\text { and torturous. }\end{array}$ & $\begin{array}{l}5,9,15,24, \\
27,31,35\end{array}$ \\
\hline $\begin{array}{l}\text { Additive } \\
\text { bilingual identity }\end{array}$ & $\begin{array}{l}\text { Learners have two sets of langu- } \\
\text { ages/cultural concepts, with each used in } \\
\text { its specific cultural situation. }\end{array}$ & $\begin{array}{l}\text { In English setting, I am very confident to show } \\
\text { modest person as required by Chinese culture. }\end{array}$ \\
\hline $\begin{array}{l}\text { Productive } \\
\text { bilingual identity }\end{array}$ & $\begin{array}{l}\text { Learners' two languages/ cul- tural } \\
\text { concepts were promoted mutually. }\end{array}$ & $\begin{array}{l}\text { Ifound I gain better understanding of my native } \\
\text { language and culture due to cross-cultural } \\
\text { comparison. }\end{array}$ & $\begin{array}{l}2,7,12,14, \\
21,23,25\end{array}$ \\
\hline
\end{tabular}

2. Interview

The material of learners' autobiographical accounts were required to present two topics as follows: 1. Please describe the cultural difference between Chinese and English in your English learning, and make a comparison to state their influence in your concepts and life. 2. What has foreign / second language learning meant to you? Describe your personal experience in terms of pains, gains, and changes. On this path of learning, where are you heading for? The 
two researchers conducted thematic analysis for all the material.

\section{Data Collection and Analysis}

The data of this study were collected in the normal class time. The participants were required to finish all the questions earnestly and truthfully, so all the questionnaire papers collected were valid. The items were entered into SPSS program for windows, version 22.0. Then descriptive statistics were used to determine the mean and standard deviation in questionnaires. Multi-ANOVA was run to test whether learners of different proficiency demonstrate different options in bilingual identities.

As for the material of learners' autobiographical accounts of English study and culture learning, the two researchers analyzed them thematically and dug out the information related to the research topic. All the information were classified in terms of bilingual types, thus providing further evidence and explanation for quantitative data.

\section{Results AND Discussion}

\section{A. Quantitative Data: Results from Questionnaire}

1. Frequency of five types of bilingual identities among subjects

In the questionnaire, there are seven items for every type of bilingual identity, thus the total score for one type for each subject is thirty-five points. Descriptive statistics (see table 2) clearly show that the bilingual type with the highest score is instrumental bilingual type $(\mathrm{M}=26.89)$, which indicates the significance of English as a tool in learners' personal development in modern society of China. The means for both additive $(\mathrm{M}=24.59)$ and productive $(\mathrm{M}=24.22)$ bilingual identities are beyond the critical value 21, suggesting that the subjects gain a new understanding of the target culture while remaining their native identity, based on which their two bilingual identities have improved each other in an interactive way, demonstrating a positive and acquisitive change. The means for subtractive and split identities are 17.85 and 17.31 respectively, which illustrate the conflicts and contradiction experienced by EFL learners. However, their means are below critical value, which means such kinds of conflicts are not common among learners.

TABLE 2.

FREQUENCY OF FIVE TYPES OF BILINGUAL IDENTITIES AMONG SUBJECTS

\begin{tabular}{|l|l|l|l|l|l|}
\hline & instrumental & subtractive & split & additive & productive \\
\hline mean & 26.89 & 17.85 & 17.31 & 24.59 & 24.22 \\
\hline Std. Deviation & 3.02 & 2.68 & 2.43 & 2.24 & 3.36 \\
\hline
\end{tabular}

2. Developmental pattern of bilingual identities across different levels of proficiency

As shown in table 3, there is significant difference in mean scores of different groups, which shows the developmental pattern of their bilingual identities. In terms of instrumental bilingual identity, the respective means from high-proficiency to low-proficiency groups are25.78, 26.09, 28.79, following a rising trend. And the difference of means between high-proficiency group and intermediate group, between intermediate group and low-proficiency group has reached significant level $\left(\mathrm{P}=.037^{*}, \mathrm{P}=.036^{*}\right)$. It is suggested that low-proficiency learners may concern more about the instrumental function of the foreign language than the cultural function, for example, to get high scores in exam, to get a certificate, to get information and to be helpful for self-promotion, etc. Interestingly, the intermediate group gets the highest mean $\left(M_{\text {subtractive }}=18.87, M_{\text {split }}=18.24\right)$ in subtractive and split bilingual identities, and it has significant difference $\left(\mathrm{P}=.048^{*}\right)$ from the low-proficiency group. The reason for such phenomenon may be that learners have experienced conflicts of cultural concepts after they reach the intermediate level. There are similar trends for both additive and productive bilingual identities, that is, the higher the learners' proficiency is, the more salient their additive and productive identities are. And it shows a significant difference $\left(\mathrm{P}=.016^{*}\right)$ between the means of two groups: the high-proficiency group and the low-proficiency group. It reveals that high-proficiency learners' understanding of different cultures tends to be more harmonious, profound, objective and comprehensive, so that they can adopt different communicative strategies in different cultural situations.

TABLE 3.

DEVELOPMENTAL PATTERN OF BILINGUAL IDENTITIES ACROSS DIFFERENT LEVELS OF PROFICIENCY

\begin{tabular}{|l|l|l|l|}
\hline \multicolumn{1}{|c|}{ proficiency } & high-proficiency group & intermediate group & low-proficiency group \\
\hline bilingual types & 25.78 & 26.09 & 28.79 \\
\hline substrumental & 17.74 & 18.87 & 16.95 \\
\hline split & 17.27 & 18.24 & 16.43 \\
\hline additive & 26.02 & 24.36 & 23.38 \\
\hline productive & 25.67 & 24.40 & 22.59 \\
\hline
\end{tabular}

\section{B. Qualitative Evidence: Results from Learners' Autobiographical Accounts}

1. Instrumental bilingual identity: English as a tool

The qualitative material illustrates that learners' instrumental bilingual identity is particularly distinct at the beginning of English study, and it goes through the whole process of second language study. At the beginning stage, 
students often pay much attention to their scores in English exam, for example, "In my junior and senior middle school days, I thought English was just a subject for exam." When they choose English as their majors in college, they begin to realize its importance in personal development, for example, "I always feel extremely anxious before the English certificate tests..... However, I always know its importance for the future career. So I know I can never give up." "My parents want me to be an English teacher in the future, and I think it's a good idea."

English learners' instrumental bilingual identity is closely related to their self-appraisal. For example, "I once took part in a national English contest, and the score made me very confident in English." "I am very proud that I can make all kinds of English instructions, English slogans when I take the part-time jobs." "when I use fluent English to introduce my city to foreign travelers, I get a sense of achievement and fulfillment and I am greatly motivated."

English learners of different proficiency all have instrumental bilingual identity, reflecting that learners' in strumental motivation is very important in China, such as getting a certificate, getting a working opportunity, etc. Also, it influences learners' self-appraisal and confidence very much, and in the long run it would an essential factor for the cultivation of learners' language and character.

2. Subtractive and split bilingual identities: conflicts between different cultures

When learners reach their intermediate level, they would sense the great discrepancy and conflicts between their native language/culture and the second ones. They feel their native language/culture are either replaced or deprived by the foreign ones. To be specific, some learners find that their proficiency in native language declines along with their improvement in English, for example, "I'm now very unsensitive to Chinese characters. I cannot spell many characters, and I don't know the meaning of many common idioms." "I pay little attention to Chinese, I must admit I don't know much about Chinese culture." In learners' daily life, their native thinking way is even replaced by the English one, for example, "when I am asked to present my opinion, I usually follow the standard format as 'firstly, secondly, thirdly...', maybe it's just because of numerous English writing experience." In addition, some learners tend to accept English culture, and hold the negative views for native one, for example, "Chinese are so conservative and they deal with everything in a very indirect way. For me, I prefer the direct American way." "Parents are always centered in Chinese family education, while English family education is contrary to this. I look forward to living in western countries." "Chinese concepts of time is loose, and I am very ashamed to see Chinese are always late for the meeting."

The above qualitative evidence is mutually confirmed by the quantitative data, indicating the divergence and conflicts experienced by English learners. These conflicts, however, "can never be seen as totally negative" (Yihong G, 2004). It is agreed that students only can have such feelings and reflections when they understand English language/culture to a certain extent. When they reflect more and more, their bilingual identities tend to be additive and productive. So we can say subtractive and split bilingual identities are a stage where learners endeavor to acquire English culture and construct their own understanding of self culture.

3. Additive and productive bilingual identities: integration of different cultures

There are also much evidence of additive and productive bilingual identities in the qualitative material, which illustrates the learners' growth in critical thinking and multi-cultural perspectives. Learners express their rational and tolerant attitudes for cultural difference in an abstract way, for example, "I don't want to determine which culture is better, Chinese or English, because they are the results of long-time accumulation. We just need to make the best of the both worlds." "English study made me not self-centered any more, and I began to see every culture equally." "Chinese culture is like a poem, while English culture is like a sensible man" "In view of cultural difference, we need to learn from others' strong points to offset our own weakness." Also, in dealing with the specific cultural situations, learners can adjust their communication styles according to different cultural settings, for example, "I would to be frank to foreigners, but to be indirect to my Chinese friends and relatives." Moreover, English study has improved learners' comprehension of Chinese language and culture, for example, "By comparison between two languages, I found Chinese so charming." In addition, learners of high-proficiency tend to hold very critical and objective viewpoints to different cultures, for example, "Westerners have advantage in creativity over Chinese, while Chinese are more attentive and careful in dealing with issues." Finally, learners' reflective consciousness also indicates their growth as well-rounded "human beings", for example, "I begin to know a totally different life style after learning English. I can integrate it into my own life." "English study is a difficult and long journey, and I find our life is just like this journey."

Learners' new-appeared additive and productive bilingual identities are regarded as positive and acquisitive changes, and it's a good opportunity to broaden their cultural horizons and remodel their cultural identities. In doing so, learners can gradually develop independent, rational, tolerant and multiple cultural identities.

\section{CONCLUSION}

By adopting both quantitative and qualitative methods, this paper, with the the types of bilingual identities (Yongwei B \& Yihong G,2006) serving as the framework, examines the characteristics of Chinese college English learners' bilingual identity changes. It was found that instrumental bilingual identity penetrates through L2 learning process, additive and productive bilingual identity are dominant types among L2 English learners, while subtractive and split bilingual identities are not the general trend in youngsters; the bilingual identity construction of EFL learners may assume the following process: instrumental bilingual identity, subtractive and split bilingual identity, additive and productive bilingual identity. The study indicates the conflicts and integration of bilingual identity experienced by L2 English 
learners of different proficiency. The results confirm the argument of "Spiral Model of the development of English learners' identity changes, that is, from unitary identity to double identities to integrative identity." (Yihong G et al, 2003)

Concerning China's circumstance, English learners' instrumental bilingual identity and cultural bilingual identity are equally important. Hence English teachers should guide students to take English into their career plan; "Content-based English learning" should be popularized in China's colleges and universities; students' intrinsic motivation in English should be cultivated so as to broaden their cultural horizon; productive bilingualism is the ideal goal of English education and should be taken as the ultimate purpose of language education; the native language/ culture should be integrated into English study to promote students' development as a whole person.

The present study, of course, cannot be exempted from drawbacks. For example, the study is conducted within the framework of five types of bilingual identities, students' identity change, however, cannot be and will never be clear-cut, so more detailed qualitative research is needed to explore the characteristics of students' identity change. This drawback needs to be taken into account in future research.

\section{ACKNOWLEDGMENT}

This study is based on and financially supported by the teaching project of Yunnan Provincial Higher Education "The Construction of Characteristic Specialty for English Majors” in Tourism and Culture College of Yunnan University.

\section{APPENDiX. QUESTIONNAIRE}

\section{A. Personal Information}

$\begin{array}{lr}\text { Gender_ Age__ } & \text { Years of learning English } \\ \text { Present English proficiency___ } & \text { (CET4 or TEM4) }\end{array}$

\section{B. Questionnaire}

Dear participants,

The following questionnaire is intended for a research on cultural identity changes. How much do you agree or disagree with each statement? Circle one of the options based on your own experience by referring to the instructions below.

$\frac{\text { Strongly disagree }}{1} \quad \frac{\text { Somewhat disagree }}{2} \quad \frac{\text { Neutral agree/Not sure }}{3} \quad \frac{\text { Somewhat agree }}{4} \quad \frac{\text { Strongly agree }}{5}$

1. With the improvement of my English proficiency,I feel my Chinese is becoming less idiomatic.

$\begin{array}{lllll}1 & 2 & 3 & 4 & 5\end{array}$

2. After learning English, I have become more interested in Chinese traditional culture and western customs.

$\begin{array}{lllll}1 & 2 & 3 & 4 & 5\end{array}$

3. English for me is a stepping-stone to get a job.

$\begin{array}{lllll}1 & 2 & 3 & 4 & 5\end{array}$

4. With the improvement of my English proficiency,I can better appreciate the subtleties in Chinese.

$\begin{array}{lllll}1 & 2 & 3 & 4 & 5\end{array}$

5. I feel weird when my speech in Chinese is subconsciously mixed with English words.

$\begin{array}{lllll}1 & 2 & 3 & 4 & 5\end{array}$

6. One important goal of my English study is to get a diploma in college.

$\begin{array}{lllll}1 & 2 & 3 & 4 & 5\end{array}$

7. I can easily switch between Chinese and English according to situational needs.

$\begin{array}{lllll}1 & 2 & 3 & 4 & 5\end{array}$

8. After learning English, I have developed repugnance to some Chinese conventions.

$\begin{array}{lllll}1 & 2 & 3 & 4 & 5\end{array}$

9. I feel a painful split when I switch between English and Chinese behavioral patterns.

$\begin{array}{lllll}1 & 2 & 3 & 4 & 5\end{array}$

10. I found my communication styles and behaviors were a little westernized after learning English for many years.

$\begin{array}{lllll}1 & 2 & 3 & 4 & 5\end{array}$

11. An instrument is an instrument. It is impossible for me to change into another person after learning a language.

$\begin{array}{lllll}1 & 2 & 3 & 4 & 5\end{array}$

12. In English setting, I am very confident to show myself. While in Chinese situations, I try to be a modest person as required by Chinese culture .

$\begin{array}{lllll}1 & 2 & 3 & 4 & 5\end{array}$

13. After learning English, I like popular music of America better and like to listen to original songs in English.

$\begin{array}{llllll}1 & 2 & 3 & 4 & 5\end{array}$

14. I prefer to listen to the original English dialogue when watching English movies, just as I enjoy the original 
Chinese dialogue when watching Chinese movies.

$$
\begin{array}{lllll}
1 & 2 & 3 & 4 & 5
\end{array}
$$

15. When parting with foreign friends, I'm frequently confused as to whether I should shake hands or hug and kiss.

$\begin{array}{lllll}1 & 2 & 3 & 4 & 5\end{array}$

16. I prefer social activities which involve only non-Chinese.

$\begin{array}{lllll}1 & 2 & 3 & 4 & 5\end{array}$

17. After learning English, I find myself more sensitive to changes in the outside world.

$\begin{array}{lllll}1 & 2 & 3 & 4 & 5\end{array}$

18. After learning English, I have begun to reject some traditional Chinese ideas.

$\begin{array}{lllll}1 & 2 & 3 & 4 & 5\end{array}$

19. After learning English, I have become more understanding and can better communicate with others.

$\begin{array}{lllll}1 & 2 & 3 & 4 & 5\end{array}$

20. As my ability of appreciating English literature and arts increases, I have become more interested in Chinese literature and arts.

$\begin{array}{lllll}1 & 2 & 3 & 4 & 5\end{array}$

21. I have an English name in addition to my Chinese name. They are used in different situations.

$\begin{array}{lllll}1 & 2 & 3 & 4 & 5\end{array}$

22. Only if I learn English, can I get a good job in the future.

$\begin{array}{lllll}1 & 2 & 3 & 4 & 5\end{array}$

23. When communicating with foreigners, we should follow both cultural habits.

$\begin{array}{lllll}1 & 2 & 3 & 4 & 5\end{array}$

24. I found traditional Chinese concepts often conflict with English concepts, which makes me confused and torturous.

$\begin{array}{lllll}1 & 2 & 3 & 4 & 5\end{array}$

25. When chatting with my classmates, I always use English words and idioms to help express myself accurately; while talking with my parents or someone else, I prefer in idiomatic Chinese or dialect.

$\begin{array}{lllll}1 & 2 & 3 & 4 & 5\end{array}$

26. I found I gain better understanding of my native language and culture due to cross-cultural comparison.

$\begin{array}{lllll}1 & 2 & 3 & 4 & 5\end{array}$

27. After learning English, I'm frequently confused how to greet to my generation or relatives.

$\begin{array}{lllll}1 & 2 & 3 & 4 & 5\end{array}$

28. After learning English, I call my teacher's name directly rather than his or her title.

$\begin{array}{lllll}1 & 2 & 3 & 4 & 5\end{array}$

29. Speaking fluent English is a symbol of good education.

$\begin{array}{lllll}1 & 2 & 3 & 4 & 5\end{array}$

30. After learning English, I am more sensitive to western values such as "personality", as well as our traditional cultural values.

$\begin{array}{lllll}1 & 2 & 3 & 4 & 5\end{array}$

31. After learning English, I found it still difficult to communicate with foreigners for the differences of culture and value.

$\begin{array}{lllll}1 & 2 & 3 & 4 & 5\end{array}$

32. I learn English just for a better job opportunity.

$\begin{array}{lllll}1 & 2 & 3 & 4 & 5\end{array}$

33. After learning English, I dare to look at others directly while talking and expressing myself with more confidence.

$\begin{array}{lllll}1 & 2 & 3 & 4 & 5\end{array}$

34. I learn English in order to learn my own major better.

$\begin{array}{lllll}1 & 2 & 3 & 4 & 5\end{array}$

35. After learning English, I'm frequently confused what I should present to a foreign friend for the differences between two cultures.

$\begin{array}{lllll}1 & 2 & 3 & 4 & 5\end{array}$

\section{REFERENCES}

[1] Gardner, R.C. (1985). Social Psychology and Second Language Learning: The Role of Attitudes and Motivation. London: Edward Arnold.

[2] Moss, K. \& Faux, W. (2006). The enactment of cultural identity in student conversations on intercultural topics. The Howard Journal of Communications, 17, 21-37.

[3] Yihong G. (2001). Foreign Language Learning: " $1+1>2$ ". Beijing: Peking University Press.

[4] Yihong G. (2004). The social psychology of English learning by Chinese college students-motivation and learners' self-identities. Beijing: Foreign Language Teaching and Research Press. 
[5] Yihong G, Chen, Zhao, Zhou. (2003). Motivation types and self-identity changes among Chinese college undergraduates. Foreign Language Teaching and Research, 2,132-139.

[6] Yongwei B \& Yihong Gao. (2006). EFL Students' self-reports of identity-construction. Foreign Languages and Literatures, 1, 34-39.

[7] Yuxin R. (2008). An investigation into Chinese EFL learners' cultural identities. Foreign Languages and Literatures, 1, 46-52.

[8] Zhanzi L. (2007). Autobiographical accounts of cross-cultural communication and English teaching. Beijing: Higher Education Press.

Fen Xue was born in Shanxi, China in 1983. She got her M.A. degree in English Teaching Methodology from Northwest Normal University, China in 2010.

She is now a teacher in Foreign Language Department, Tourism\& Culture College of Yunnan University, Yunnan, China. She's interested in applied linguistics and second language acquisition.

Baijing Han was born in Gansu, China in 1982. He got his M.A. degree in English Teaching Methodology from Northwest Normal University, China in 2010.

He is now a teacher in Foreign Language Department, Lijiang Teachers' College, Yunnan, China. His research interests include cognitive linguistics and comparative study of Chinese and English. 